\title{
Environmental challenges of trans-boundary water resources management: the case of Bangladesh
}

\author{
Mohammed Abdul Baten ${ }^{1} \cdot$ Rashed Al Mahmud Titumir ${ }^{2,3}$
}

Received: 4 March 2015/Accepted: 11 November 2015/Published online: 24 November 2015

(C) Springer International Publishing Switzerland 2015

\begin{abstract}
The political definition of 'natural geography' with regard to trans-boundary waters may pose challenges to their environmental importance. Availability and distribution of trans-boundary waters may thus give rise to dissatisfaction, disbelief and dispute among its stakeholders. The Ganges, Brahmaputra and Meghna (GBM) basins, shared between Bangladesh and India, as a whole, receive more water than necessary over the year, but the spatial and temporal distribution of water availability are very uneven. Focused on the trans-boundary water regime of the GBM basins, this paper discusses core issues related to environmental security by analyzing various environmental impacts due to water diversion and its significance at the national and regional levels between Bangladesh and India. Both countries have built dams and barrages on these rivers to satisfy their water needs without considering the ecological settings. Consequently, the dwindling supply of water in dry season has become one of the key contested issues between the two countries. Negotiations, however, for water sharing in this region are mostly based on anecdotal rather than scientific evidences. Both Bangladesh and India classify river flow data as secret and use the lack of mutually acceptable data as a tactic to promote their own
\end{abstract}

Mohammed Abdul Baten

a.baten@iub.edu.bd; baten_123@yahoo.com

Rashed Al Mahmud Titumir

rtitumir@unnayan.org

1 School of Environmental Science and Management, Independent University Bangladesh (IUB), 16 Bashundhara R/A, Dhaka 1229, Bangladesh

2 Department of Development Studies, University of Dhaka, Dhaka, Bangladesh

3 Unnayan Onneshan, Dhaka 1216, Bangladesh national interests. Reviewing the environmental challenges, the paper opines for an ecosystem orientation of international norms and regimes flows for the GBM basins.

Keywords Bangladesh · Environmental security · GBM basins $\cdot$ Water sharing $\cdot$ Water diversion

\section{Introduction}

Trans-boundary fresh water resources management has become complex because of water scarcity due to increased water demand and climate change associated precipitation variability (Biswas et al. 2004). Such water scarcity has led to conflict between countries, between local government institutions within countries and between sectoral users or groups within countries (Uitto and Duda 2002). Disputes over valuable water resources mostly discussed as political issue but their environmental security remains a less important issue on the agenda of trans-boundary water discussion. Thus the political definition of 'natural geography' of trans-boundary water resources overwhelms their environmental importance (Wolf et al. 2005). Moreover, complexity from natural in-equilibria may add tension in the 'power base' for geo-politics, which may have been reflected in hydro-diplomacy (Farooque 2004).

Bangladesh and India are close neighbours, who share 4096.7 kilometers $(\mathrm{km})$ land borders and 54 rivers (Rashid 1977). Despite having similarities in history, geography, and politics, water sharing between these countries is characterized by discontent, disbelief and mistrust (Nishat and Faisal 2000). Hence, political concept of environmental security and trans-boundary resource management receive more attention than ecological dynamics in this context. 


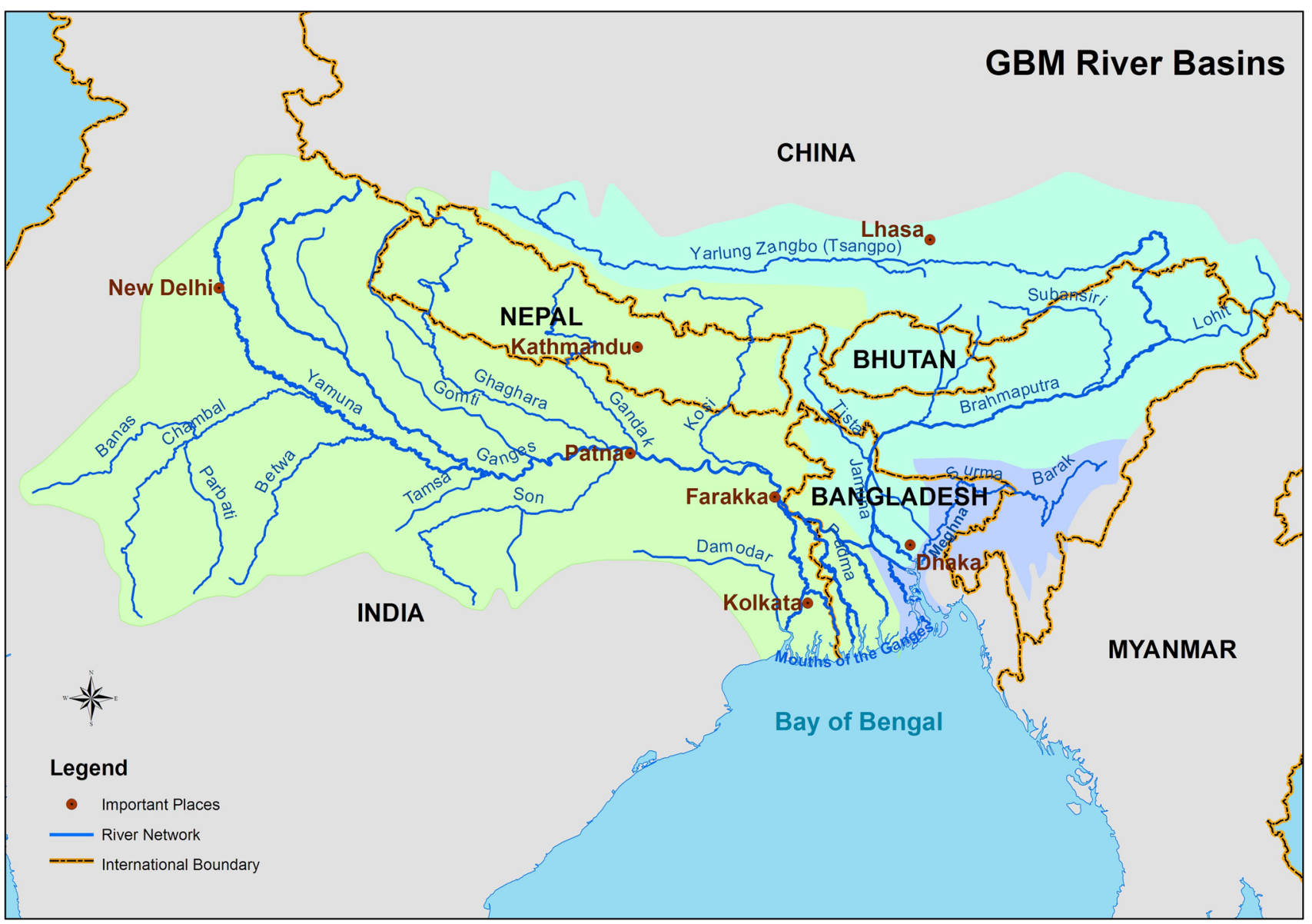

Fig. 1 The Ganges-Brahmaputra-Meghna (GBM) Basins

Bangladesh has a total of 230 rivers with their tributaries and distributaries that crisscross the country forming a web-like structure originating both in and outside the country (BBS 1997). The Ganges (G), the Brahmaputra (B) and the Meghna (M) rivers and their distributaries collectively known as the GBM basins (see Fig. 1), constitute major part of the river systems in Bangladesh that drain a total area of about 1.72 million $\mathrm{km}^{2}$ (Ahmad et al. 2001) and finally the combined flow is discharged into the Bay of Bengal. The GBM region constitutes the second largest hydrologic region in the world. It stretches through five countries: Bangladesh, Bhutan, China, India (16 states in the north, east and northeast, in part or fully), and Nepal (Chaturvedi 2011). Bangladesh and India share all the three river systems; China shares the Brahmaputra and the Ganges, Nepal only the Ganges, and Bhutan only the Brahmaputra (Faisal 2002). The GBM basins, as a whole, receive more water than required for sustaining life and economy of their watershed areas (Bandyopadhyay and Perveen 2008), where Bangladesh is a downstream country that receives many of these common rivers at a mature state-when the velocity drops, sedimentation rates increase, and the river changes its course, braiding into multiple channels. These rivers collectively discharge 1.5 million cubic meters of water per second $\left(\mathrm{m}^{3} \mathrm{~s}^{-1}\right)$ during the peak period, but the runoff is only about $61,000 \mathrm{~m}^{3} \mathrm{~s}^{-1}$ in lean period (Hasan and Mulamoottil 1994). Among these rivers, the Brahmaputra and the Ganges account for $80 \%$ of the flow measured within the country, and the Meghna contributes only $2 \%$ of the total measured discharge in Bangladesh during March-April (World Bank 2000).

In many instances upper riparian countries have capitalised their geographic advantages by building dams and barrages for irrigation, transportation and other purposes, but environmental consequences are mostly borne by the lower riparian countries (Kliot et al. 2001b). Kliot et al. (2001a) have examined the management systems of 12 trans-boundary river basins: The Mekong, Indus, GangesBrahmaputra, the Nile, Jordan, Danube, Elbe, Rio Grande and Colorado, Rio de la Plata, Senegal and Niger and found a direct linkage between water scarcity and unequal distribution, where the 'powerful' ${ }^{1}$ ' countries have been found controlling the maximum flow for their use. Based on

\footnotetext{
${ }^{1}$ Powerful country understood as influential country in terms of military, economic and diplomatic strengths.
} 
available information and case studies, Falkenmark and Rockstom (2000) argue that conflict on water resource not only is resultant of physical scarcity, but also is very relevant to socio-political dimensions such as distribution, rational use and equity. To some extent the argument is also true for Bangladesh and India water relations, which have been plagued with uneven spatial and temporal distribution of water and inadequate information sharing (Adhikary et al. 2000). Despite Bangladesh's overwhelming dependency on the GBM rivers for livelihood and agriculture, the country is unable to manage water resources of these rivers on its own as 92 percent of the GBM basins are situated outside the country (Faisal 2002; Wirsing et al. 2013). Thus dwindling supply of water in the dry season has become one of the key contested issues between Bangladesh and India (Nishat and Faisal 2000).

Since Bangladesh and India's environment and livelihood are heavily dependent on the rivers of the GBM basins, hence any unilateral or asymmetrical management practice or decision would bring catastrophic damages to the whole region (Wirsing et al. 2013). However, the history of these river systems is characterised by human interventions both at up and down streams despite their critical role to serve livelihood to the hundreds of millions people of the GBM basins (Farooque 2004). Many of those interventions are relating to shifting river flows that would profoundly affect peoples' social, economic, and cultural lives as well as disrupt the ecological integrity of the region (Faisal 2002). Not exclusively, but frequently, India, being the upper riparian country, has been blamed for creating obstruction in natural flows of the GBM basins through dams and barrages that might be one of the significant causes of low inflow in lower riparian Bangladesh during dry season (Faisal 2002). Since $80 \%$ of Bangladesh's annual fresh water supply comes from these trans-boundary rivers, obstructions in inflow of water can result into serious environmental degradation (Nishat and Faisal 2000).

The water sharing of common rivers between Bangladesh and India, particularly the GBM rivers, is attributed with various contentions at temporal and spatial scales (Adhikary et al. 2000). At first, the dispute between Bangladesh and India regarding water sharing came to public domain in 1951 when Bangladesh was a part of Pakistan (Bangladesh, then known as East Pakistan, became an independent country in 1971). At that time India decided to construct the Farakka Barrage in order to divert water from the Ganges to the Hoogly River through a 42-km long feeder canal with a carrying capacity of $1113 \mathrm{~m}^{3} \mathrm{~s}^{-1}$ (Abbas 1982). After a long techno-political debate, finally the Barrage was constructed in 1975 at Farakka point of Fulertal, just $18 \mathrm{~km}$ from the Bangladesh border. Bangladesh showed its dismay as regards the construction of the Farakka Barrage, but India argued that Bangladesh would need a small part of the historic flow of the Ganges and most of its flows are wasted in the Bay of Bengal. This Barrage, on the other hand, would benefit India by allowing them to divert the Ganges water into the Bhagirati-Hoogly river that would flush the accumulated silts from the riverbed and improve navigability at the port of Calcutta (now Kolkata) (Abbas 1982; Faisal 2002; Nishat and Faisal 2000; Sharma and Sharma 2008). But the post-construction reality presents a different scenario for Bangladesh in its water resources and associated sectors. Analyzing preFarkka (1949-1970) and post-Farakka (1975-1995) data of inflow of water at the Hardinge point (Bangladesh part), Tanzeema and Faisal (2001) found that the average inflow during dry season of the Ganges reduced to $51 \%$ during the period. Such a drastic drop in the flow of the Ganges water in the dry season resulted in significant ecological and economic damages for Bangladesh (Bharati and Jayakody 2011; Crow et al. 1995; Faisal 2002; Mirza 2004).

To address and resolve trans-boundary water sharing challenges between the two countries, there exists a dispute resolving mechanism-the Joint Rivers Commission $(\mathrm{JRC}){ }^{2}$ In spite of this, the countries continue to face disagreements over how to allocate and share waters from the Ganges and the Teesta including several other common rivers. It remains also unclear how the countries would plan to augment the flow of depleted rivers (Faisal 2002). Even though modes of basin wide negotiations may vary, it is important for the riparian countries to share hydro-meteorological, physical, environmental and socio-economic data for the integrated management of the river basins and water resources (Biswas et al. 2004). Information sharing can usually provide confidence-building measures among riparians. Unfortunately, both Bangladesh and India often classify river flow data as 'secret' and use the lack of mutually acceptable data as a tactic to promote own national interests (Abbas 1982; Beach et al. 2000). Therefore, inaccessibility to adequate data and insufficient knowledge of the ecological processes regarding the Himalayan rivers have resulted in increasing ecological complexity of the GBM region (Bandyopadhyay 1992, 2004; Bandyopadhyay et al. 1997).

Snow and glacial melt are important hydrologic processes in the origin of these GBM rivers (Cruz et al. 2007). Climate change has added a new dimension to glacial melting and subsequent hydrological characteristics of these rivers. Using the Normalized Melt Index (NMI) ${ }^{3}$ over

\footnotetext{
2 The Joint Rivers Commission (JRC) was established on 24 November 1972 to deal with sharing of water of the common rivers between Bangladesh and India.

${ }^{3}$ NMI is defined as the volumetric snow and glacier upstream discharge divided by the downstream natural discharge.
} 
the period 2001-2007, Immerzeel et al. (2010) argued that Asian rivers are mostly threatened by climate change, yet the effects of climate change on availability of water and food security in Asia differ substantially among basins and cannot be generalised. They reported that the Brahmaputra basin is likely to be severely affected due to the large population and the high dependence on irrigated agriculture and melt-water. Likewise, increased glacier melting will result in increased flows of water in the Ganges River in the short term which is likely to cause severe floods. In the long term, flow could drop by up to two-thirds, which may result in severe scarcity of water (Sharma and Sharma 2008). It seems both human interventions and natural factors make the management complex for these transboundary rivers from a benefit accrual as well as water environment management point of view.

Focusing on the trans-boundary water regime of the GBM basins, this review therefore discusses the core issues related to environmental impacts arising from transboundary water management and their significance at the national and regional levels. More specifically, this article critically examines trans-boundary water relations between Bangladesh and India and related environmental security issues in Bangladesh context.

\section{Conceptualizing environmental security}

The issue of 'Human security' and 'Environmental change' has been a matter of discourse both in academia and policy forum for decades. But environmental factors are poorly incorporated in national human security studies. The narrow interpretation of human security, in terms of 'freedom of fear' overlooked environmental components in many instances. With the emergence of complex environmental problems, and rapid pace of global environmental change, the widening of the security concept has been sought to incorporate the concept of environmental security (Dalby et al. 2009). Ullman (1983) explained the concept of human security as "a threat to security includes (any) action or sequence of events that (1) threatens drastically and over a relatively brief span of time to degrade the quality of life for the inhabitants of a state, or (2) threatens significantly to narrow the policy choices available to the government of a state or to private, nongovernmental entities (persons, groups, corporations) within the state". The definition essentially indicates environment as a source of conflict. Accordingly, the Brundtland (1987) report argued that the security concept must be expanded to include the growing environmental concerns. In response, there have been few attempts so far to combine the 'environmental' (including water, food, health, and livelihood) with the human security approach (Dalby et al. 2009).
Contemporary human security analysis also does not oppose the trends of redefining security or mapping the environmental roots of violent conflict (Najam 2003). Myers (1993) also supported extended definition of human security and argued that human and environmental securities are interrelated.

The study of 'environmental security' received momentum in the US, followed by other parts of the world, in the waning years of the cold war based on the assumptions that environmental disruptions which would lead to conflict were common; even more so were fears of wars to control scarce resources, and alarmist accounts of imminent chaos as environmental decay fed numerous social problems (Dalby et al. 2009). Since development of the concept, 'environmental security' has been observing a gradual shift over the last couple of years, from an early focus of incorporating environmental and related concerns, to a new focus of searching the causes of conflict due to environmental changes. It is assumed that this shift is influenced by recent technological developments which help to identify inherent causes of problem vis-à-vis growing list of environmental problems and their associated risks to the human beings (Dabelko et al. 2000; Elliott 2001). Dalby et al. (2009) categorizes the development of 'environmental security' research (1983-2006) into three major phases: the first phase focused on concepts and their legitimization; the second phase focused on theory oriented and empirically based with a strong emphasis on case studies; and the third phase focused on plurality of methods, from qualitative case studies on environmental change to quantitative assessment of trans-boundary resources management and exploring causes of violent conflicts.

\section{Water sharing negotiation between Bangladesh and India: an ambivalent history}

There exists different views on the mode of negotiation of water sharing between Bangladesh and India-whether it should be bilateral or multilateral, in turn, creates significant challenges for coming to a fair agreement between the countries (Faisal 2002). Bangladesh is interested to include Nepal and Bhutan in the trans-boundary water discussion. India prefers the negotiations to remain bilateral. Here Bangladesh argued that Nepal and Bhutan should be included in the negotiations as sharers of the basins, India on the contrary has opined that Nepal could have its own plans and priorities that might not match with the requirements of Bangladesh (Haftendorn 2000; Faisal 2002). Another debate on negotiation evolves from management of the basins. Bangladesh has been interested to resolve issues relating to water sharing within each river basin separately, while India has argued that all three major 
rivers form an interconnected system and should therefore be treated as a single, integrated unit (Faisal 2002). India's proposal on linking all major rivers by constructing a dam on the Brahmaputra River for augmentation of flow is based on this view of considering the GBM basins as a single unit. Bangladesh, albeit others, preaches that planning and management of the GBM rivers as one system is quite difficult and in some cases impossible because of its sheer size, complexities and multinational character (Biswas 2008).

\section{The Ganges water sharing}

The political contestations and asymmetries overwhelm the Ganges water dispute on the one hand as well as resultant extreme poverty and ecological degradation on the other (Haftendorn 2000). Even though several attempts were pushed forward, mostly from the Bangladesh side in response to aforementioned problems, the process has yet to produce a fare, workable solution. Looking at the diplomatic relations between these two countries, it is commonly observed that the Indian Congress Government shows a positive attitude when Bangladesh Awami League is in power (Faisal 2002; Nishat and Faisal 2000). This is not particularly surprising since India actively helped and supported Bangladesh independence in 1971 under Awami League's lead. But, the Indo-Bangladesh relations went through an upheaval in 1975 with the construction of the Farakka Barrage. After a 2-year deadlock, the water sharing negotiation revived with a 5-year agreement in 1977 where both parties agreed to continue the talks on augmentation of the flow of the Ganges River during dry season (Faisal 2002; Haftendorn 2000; Haque 2008). Accordingly, both countries exchanged proposals in 1978; but none of those were finally accepted.

India had proposed to transfer water from the Brahmaputra River through a gigantic canal that would run from Jogighopa in Assam, across northern Bangladesh, to just above the Farakka. Bangladesh, in contrast, proposed to divert water from the Gandak and Kosi River (Faisal 2002). With these contrasting positions on the process of augmentation of flows, the Ganges water sharing agreement was extended for another 5 years in 1982. Later in 1983, both the countries submitted their updated proposals, where Bangladesh suggested to build seven dams in Nepal and Bhutan at upper flow of the Brahmaputra and the Ganges in order to fulfill the water needs of the region (Haftendorn 2000; Faisal 2002). India slightly revised its earlier proposal and expressed their intention to build a barrage at Jogighopa and three dams at Dihang, Subansiri, and Tipaimukh and divert the Brahmaputra water through a $324 \mathrm{~km}$ long link canal crossing northern Bangladesh reaching the Ganges (Faisal 2002). Again, neither country accepted the other country's proposal by arguing that their counterpart's proposal would hamper their social, ecological and economic conditions.

The First Ganges Water Sharing Agreement between Bangladesh and India was signed in 1977 and expired in 1988 after a single renewal. Following this period, there was no agreement effective on the sharing of water of the Ganges between two countries for the period of 1989-1996. During this time, the release of water to downstream through the Farakka Barrage was only at India's mercy and Bangladesh routinely received low flow during the period (Haque 2008). Bangladesh experienced many problems due to scarcity of water, particularly in the lean period and raised the issue in many different forums.

After 8 years of continuous bilateral discussions, both at expert and political levels, Bangladesh and India signed a new agreement on the sharing of water of the Ganges on 12 December 1996, commonly known as the Ganges Treaty, which is meant to remain valid for 30 years (Faisal 2002; Haque 2008; Nishat and Faisal 2000). The 1996 agreement expounds the availability of the water of the Ganges at the Farakka point, based on the flow data between 1949 and 1988 (Haque 2008). Both countries have committed themselves to a complicated formula, where during the dry season (from 1 January until 31 May) the upstream country has to sustain a minimum water level of 35,000 cusecs (cubic feet per second) for its counterpart at every alternate 10-day period. Bangladesh will receive a minimum 27,633 cusecs and India will get a minimum 25,992 cusecs during those days. However, if the flow comes down to $60,000-50,000$ cusecs at the Farakka, the share would be divided equally between the countries (Annexure 1, the Ganges Treaty 1996).

With some criticisms on modus operandi, the Ganges treaty could be cited as a good example of trans-boundary water sharing agreement that upholds the spirit of "equity, fairness and no harm to either party" (Article IX, the Ganges Treaty 1996). Based on these principles, the treaty also urges both governments to resolve water sharing problems of other common rivers and calls for a strong desire of the partners for a more equitable use of the Farakka Barrage water (Kliot et al. 2001a). Moreover, the article III of the Ganges Treaty strongly discourages to reduce water below the Farakka on India's by mentioning "the waters released to Bangladesh at Farakka under Article I shall not be reduced below Farakka except for reasonable uses of waters, not exceeding 200 cusecs, by India between Farakka and the point on the Ganga/Ganges where both its banks are in Bangladesh" (Article III, the Ganges Treaty 1996). However, the water sharing proportion between Bangladesh and India was found out to be asymmetrical and water use was been recorded at 45:55 and in some cases at 30:70, which gave rise to heated 
disputes in Bangladesh (Khalid 2004). Lebel et al. (2010) also found evidence of asymmetrical water sharing and claimed that the Farakka Barrage diverts as much as $60 \%$ of the natural flows for large-scale irrigation to the Indian part. Another concern for Bangladesh has been that there is no guarantee clause to release the minimum quantity of water in case of abnormally low flows.

By analysing the 1977 and 1996 water sharing agreements, Nishat and Faisal (2000) have argued that neither agreement helped to improve availability of water in Bangladesh during the lean season. In this regard, the 1996 treaty performed more poorly than the 1977 agreement during the most critical 10-day periods of March and April. They concluded that these agreements essentially validated the status quo position of India rather than providing Bangladesh its historic share of water. The water flow data of pre-1975 at the Hardinge bridge (inside Bangladesh) supports their statement since it shows that during that period Bangladesh received more or less 70,000 cusec in dry season (Haque 2008). Another significant drawback of the treaty is that it is overwhelmingly concerned about sharing of water during lean period, and therefore overlooks the fact that the Ganges is also a major cause of monsoon floods (Khalid 2004). Even though Bangladesh has raised the issue several times, India confined sharing of water to only during lean period and pledged to share flood forecasting information under SAARC (South Asian Association for Regional Cooperation) umbrella (Haftendorn 2000; Haque 2008).

\section{Indian river linking project}

Agreements were signed between Bangladesh and India on sharing of water; yet the countries have not been able to come to a comfortable position. Many disputes have evolved over the years. One of the outstanding issues that has become a concern for Bangladesh is the Indian River Linking Project (IRLP). The proposal was conceived in 1982 by the late Prime Minister Indira Gandhi, based on an assumption which argued that the Ganges-Brahmaputra basins have too much water, but the southern India suffers from scarcity of water. The project, therefore, was planned to link all the major rivers in India by diverting water from the Ganges-Brahmaputra basins through networks of channels, reservoirs and dams (Bandyopadhyay and Perveen 2008). At the initial stage, the project had proposed linkages of 30 rivers, 3000 storage structures and $14,900 \mathrm{~km}$ of canals to shift water to western and southern India including water from the Ganges-Brahmaputra basins to the Mahanadi basin (Amarasinghe et al. 2008; Mirza et al. 2008). But, the progress of the plan remained minimal until 2002 when the Indian Supreme Court, in response to a public interest petition, revived the project.
The Indian Supreme Court issued an order to the government on 27 February 2012 to implement the rivers-linking scheme in a 'time-bound manner'. The Court's overarching focus was 'national interest' and it observed:

"This is a matter of national benefit and progress. We see no reason to why any state should lag behind in contributing its bit to bringing the inter-linking river programme to a success, thus saving the people living in drought-prone zones from hunger and people living in flood-prone areas from the destruction caused by floods" (cited in Amarasinghe et al. 2008).

The river-linking project has identified total 30 links, of which 14 links are under the Himalayan component and rest of the links are designed for the Peninsular component (Rashid 2012a). Despite Bangladesh's repeated concern on likely consequences of the river linking project, feasibility reports of 14 links under the Peninsular component and 2 links under the Himalayan component (Indian portion) were prepared without any consultation with Bangladesh. Bangladesh alleged that the plan of linking trans-boundary Himalayan rivers is against the spirit of the 2010 Bangladesh-India joint communiqué and the Framework Agreement on Cooperation and Development signed on 6 September 2011. Moreover, the plan conflicts with Article IX of the 1996 Indo-Bangladesh Ganges Water Treaty (1996) and the 1992 UN Convention on Biological Diversity (UNCBD).

The river linking project raises many issues on social and environmental grounds, such as displacement of people, environmental impacts and trans-boundary impacts to Nepal and Bangladesh (Amarasinghe et al. 2008). Environmentalists are also skeptical as to the usefulness of the proposed river links: reducing the water scarcity problems in drought prone areas seems difficult due to their distance from major rivers and high elevations (Alagh et al. 2006). Another significant threat may be observed in the fishery industry. Arresting natural flow of the rivers at a huge scale could hamper life cycles of fisher folk communities, leaving thousands of fishermen jobless both in India and Bangladesh (Bandyopadhyay 1992). However, both risks and benefits are mostly perceived based on previous experiences since no social and environmental impact assessment report has yet been shared neither with Bangladeshi citizens nor the citizens of India (Rashid 2012a).

\section{The Teesta water sharing}

The Teesta, an important tributary of the Brahmaputra River system, is one of the examples where both Bangladesh and India have built barrages for irrigation. Although the barrages contributed significantly to increased agriculture production, the list of environmental consequences is also exhaustive. On the Bangladeshi side, availability of 
water in the dry season, which has dropped significantly, has influenced Bangladesh to demand equitable water sharing (Adhikary et al. 2000). Accordingly, after a series of bilateral discussions, both countries agreed to share the Teesta water, where $80 \%$ water would be shared at the rate of 42.5 and $37.5 \%$ between India and Bangladesh respectively, keeping remaining $20 \%$ water for natural river flow (Rashid 2012b). The flow of water will be measured at the Gazaldoba point, $25 \mathrm{~km}$ away from Shiliguri, India. Preparation was done to sign an initial 15-year agreement on sharing of water of the Teesta on the occasion of Indian prime minister's visit to Bangladesh in 2011, it was finally abandoned due to last-minute opposition from the Chief Minister of Indian province of West Bengal, Mamata Banerjee, who demanded sharing ratio of water as 75:25 between India and Bangladesh. However, the Teesta accord could be cited as the first example of cooperation between India and Bangladesh, where both countries reached in an agreement in 1973 to close the gap between embankments that were separated by the boarder (Nishat and Faisal 2000).

\section{The Tipaimukh dam project}

Several agreements were signed between Bangladesh and India in order to augment flow and sharing of water, but outcomes are under critical scrutiny whether the downstream country has been receiving the specified amount (Nishat and Faisal 2000). Despite Bangladesh's dissatisfaction over sharing of water of the Ganges and other shared rivers, India has come up with a proposal for constructing a dam on the Barak River, $500 \mathrm{~m}$ downstream of the confluence of the Barak with Tuivai in Churachandpur district of Manipur, near the border of the Indian provinces of Manipur-Mizoram (INHPC 2012). The purpose of the dam is to control flood and generate hydroelectric power, as stated by the Indian National Hydroelectric Power Corporation Ltd (INHPC limited), a state owned corporation.

The Barak is a trans-boundary river, originating from the Manipur hills of northeast India and flows west to enter into Bangladesh, where it is named as the Surma River, and then flows to south as the Meghna River, a total of $946 \mathrm{~km}$ (669 km within Bangladesh) to the Bay of Bengal. The Barak divides into two parts in Karimgonj district (India), with the northern branch called the Surma River and the southern branch called the Kushiyara River. At this point the river enters Sylhet (north Bangladesh) which forms the Surma basin. The confluence of the Surma and Kushiyara formed the Meghna River inside Bangladesh above Bhairab Bazar. The Meghna joins the Padma (combined flow of the Ganges and the Brahmaputra) near Chandpur district of Bangladesh and subsequently flows to the Bay of
Bengal in the name of the Meghna. The waters of the Meghna/Barak basin have unequivocal importance in checking salinity in response to rise of sea levels. The proposed Tipaimukh dam would regulate flow out of the Surma and the Kushiara rivers, upon which large wetland ecosystem of north-eastern part lies (namely Tanguar Haor, Hakaluki Haor, Hail Haor) and serves millions of people's livelihood, including supporting rich biodiversity. The government of Bangladesh has expressed its concern on the likely impact of the dam on the flow of water and consequential implications on the whole basin.

The Tipaimukh dam proposal was unveiled by India in the first joint river commission meeting in 1972, when the primary purpose was envisaged as mitigation of floods (Bisht 2012). Both the countries then agreed to carry out a joint study on situation of flood in Cachar of India and Sylhet in Bangladesh including its socio-economic impacts. Later in 1978, hydro-power generation was added to the original flood control purposes, thus the Tipaimukh dam entered in the lexicon of the JRC and a decision was made to conduct a joint study on the engineering feasibility of the dam which would include mapping out of the benefits. But the decisions were not translated into action. Over the years, Bangladesh repeatedly raised its concern on the Tipaimukh dam location, considering its position in an ecologically sensitive and topographically fragile region, which falls under one of the most seismically volatile regions on the planet (Hoque 2012). Bangladesh has asked India to share information on the design of the project. As follow up, Bangladesh had expressed deep concern on a number of issues related to the adverse downstream impacts of the dam in the JRC meeting held in September 2005 in Dhaka (Bisht 2012). In that meeting, India formally promised to share the project design of the Tipaimukh. This has not yet been done. Instead, what was made public was the Environmental Impact Assessment (EIA) report. Environmentalists and water experts of Assam, Mizoram and Monipur of India have raised criticism of the depth of the EIA report (Mahmood 2009). The EIA report proposed to adopt recommendations from the Shukla Commission report that recommended construction of a pick-up barrage at Fulertal, $95 \mathrm{~km}$ downstream of the site of the dam that would act as diurnal storage of $1120 \mathrm{~m}^{3}$ inclusive of power release to irrigate subsequently a gross command area of 1,20,337 ha (cited in Mahmood 2009). Bangladeshi experts had reservations on this planned diversion, even if officially India has stated that no water would be withdrawn under this project in the upstream. Bangladesh spontaneously conducted its own study in 2005 by the Institute of Water Modelling (IWM) ${ }^{4}$ on the

\footnotetext{
${ }^{4}$ An autonomous research organization works under the auspices of Ministry of Water Resources, Bangladesh.
} 
potential hydrological impacts of the Tipaimukh dam using available data of rainfall and flow of water of the Barak River. The Bangladeshi IWM study (IWM 2005) estimated that the Tipaimukh dam might reduce average annual monsoon inflow around $10 \%$ in June, $23 \%$ in July, $16 \%$ in August and $15 \%$ in September at Amalshid point from the Barak River to the Surma-Kushiyara-Meghna river system. As a result, water levels in the Kushiyara River may reduce more than $1 \mathrm{~m}$ on an average at the Amalshid point during the month of July, but Fenchuganj, Sherpur and Markuli stations may experience a $0.25,0.15$ and $0.1 \mathrm{~m}$ reduction respectively. The Surma River would also experience a water level drop by $0.75 \mathrm{~m}$ and $0.25 \mathrm{~m}$ at Kanairghat and Sylhet stations in the same months. During a relatively drier monsoon year, the dam would have more impact on availability of water in the Barak-SurmaKushiyara river system than for an average monsoon year.

\section{Environmental impacts of water diversion of trans-boundary rivers at upstream}

Rivers' courses have been continuously changing mostly due to natural causes, but sometimes with human interventions in the form of dams, embankments, etc. When cost of human interventions outweighs the benefits, the consequences are to be borne by the persons affected (Rosenberg et al. 2000). It is reported that 117 rivers have dried up in Bangladesh due to obstructions and withdrawal of water in their upper reaches (Rashid 2012b). In Bangladesh, regular and adequate water supply is needed, especially during the dry season (November-May) from the Ganges for maintaining its agricultural production, continuing domestic and industrial purposes, regulating flows of its distributaries, maintaining river depths, sustaining fisheries and forestry, and keeping salinity levels under an admissible limit which would otherwise penetrate towards landward (Mirza 2004). Although the Farakka Barrage creates an opportunity for the upper riparian to use the water abundantly, it is also frequently reported for not satisfying demands of the lower riparian (Haftendorn 2000). The Farakka Barrage has been facilitating navigation at Kolkata port of India at some cost of reduced flow of water in the river systems of Bangladesh (Mirza and Sarker 2004). Various studies have found marked contrasts in available water supplies downstream between the pre- and post- Farakka periods, even during the dry season (Crow et al. 1995; Tanzeema and Faisal 2001; Mirza and Hossian 2004). It is estimated that the ratio of maximum and minimum discharge at the Hardinge Bridge stood roughly $70 \%$ and $27 \%$ between pre-Farakka and post-Farakka period (FPCO 1993). Although there have been other water diversions constructed upstream, most of Bangladeshi attention has focused on the Farakka because of its critical role in supplying freshwater to important ecosystems that are necessary for maintaining both biodiversity and livelihood. A number of significant downstream environmental consequences have already been observed in Bangladesh.

\section{Hydrological changes}

Debates over impacts of the Farakka Barrage are mostly based on general observations and anecdotal evidence rather than sound analyses of relevant data, though there are some observed impacts in Bangladesh side (Mirza 2004). A few studies have concluded that the Farakka Barrage, even allowing for influences from precipitation, river gradient and other natural factors, has resulted in significant changes in hydrology of the Ganges River system ${ }^{5}$ (in Bangladesh the river system is known as the Padma) (Bharati and Jayakody 2011; Mirza and Sarker 2004). As precipitation varies from year-to-year and regulates river discharge, a decrease in precipitation in the upstream drainage basin in India and Nepal might be one of the possible explanations that could regulate river discharge. Mirza et al. (1998) analysed precipitation records of 10 meteorological subdivisions located at the Ganges basin in India for the period 1871-1994 and 66 stations in Nepal for the period 1971-1990 and could not identify any significant increasing or decreasing trend of precipitation (the only exception is East Madhaya Pradesh that showed slight decreasing trend). Therefore, decreasing mean discharge in the Ganges and the Gorai River should not be only attributed to precipitation changes (Mirza 2004). Many studies strongly indicate that water diversion/withdrawal in the upper riparian areas might be the most significant factor for hydrological change in the lower riparian countries (Bharati and Jayakody 2011; Crow et al. 1995; Faisal 2002; Mirza 2004; Mirza et al. 2008). Due to reduced flow in the Ganges system, Bangladesh has been experiencing a wide range of socio-economic and environmental impacts including increased salinity in the southwestern part of Bangladesh. Various studies were conducted on different aspects of water diversion at upstream and its consequences on downstream (Crow et al. 1995; Khan 1993, 1996; Mirza 2004) (Fig. 2). These studies concluded that due to upstream water diversion, particularly through the Farakka Barrage, fresh water supply downstream decreases considerably. Reduced river flow restricts navigation, creates disturbance in fish habitat, reduces soil moisture, lowers ground water table and ultimately threatens economic livelihood. More

\footnotetext{
5 In Bangladesh, the Ganges River system (locally known as the Padma) is comprised of the main Ganges river; the Mahananda, an important tributary; and the Mathabanga and Gorai, two distributaries.
} 


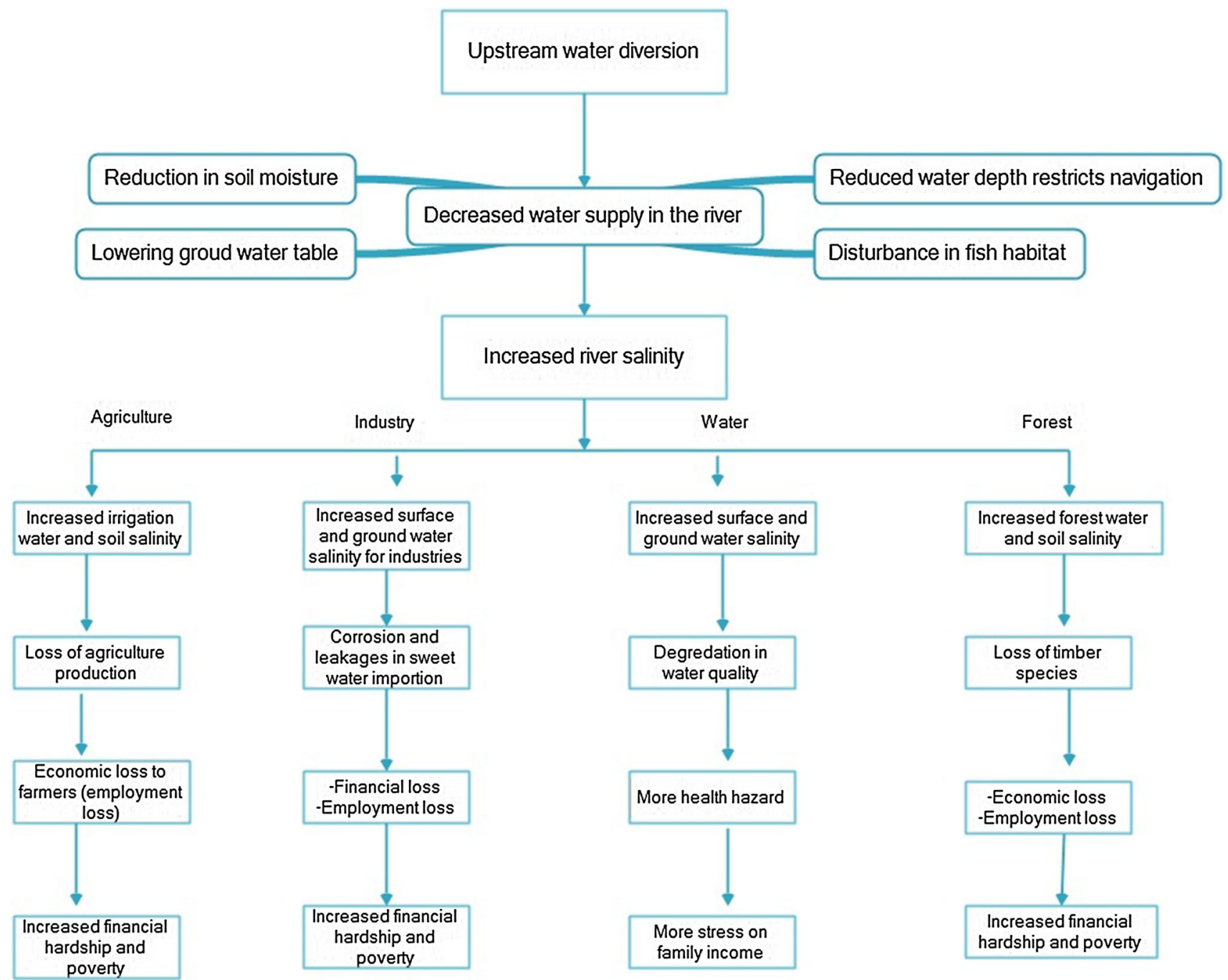

Fig. 2 Impacts of upstream water diversion to Bangladesh (Source: summarizes from Crow et al. 1995; Mirza and Hossian 2004; Mirza and Sarker 2004)

importantly, due to reduced freshwater flow, salinity intrudes towards landward, which is otherwise needed to check back water flow. Increased river salinity hampers irrigated agriculture, reduces efficiency of industries, pollutes drinking water, retards regeneration and growth of forest trees and all these effects cumulatively result in expanded poverty (Fig. 2).

The Farakka Barrage controls the normal flow of water and decreases water velocity. Due to reduced river current velocity during lean period, the rate of sedimentation is quite high, resulting in decrease in river depth/loss of navigability (Nishat and Faisal 2000). Mirza (2004) analysed stage-discharge relationship and found that siltation in the Gorai River increased beyond the natural limit. Reduced supply of water in the Gorai River also results in a virtually dried-up condition during the lean period.

\section{Salinity increase in the southwestern region of Bangladesh}

Based on BWDB (Bangladesh Water Development Board) hydrological data of 1934-1998, Mirza and Sarker (2004) claimed that India had unilaterally withdrawn water between June 1975 and November 1977 through the Farakka Barrage. After commissioning the Farakka, the discharges of the Ganges, particularly the Gorai River (the main distributary of the Ganges river systems in the southwestern region of Bangladesh) dropped sharply. Mirza (2004) reported a $73 \%$ decrease of discharge in March 1997 in the Gorai River from a pre-Farakka mean of $190 \mathrm{~m}^{3} \mathrm{~s}^{-1}$. After signing the 1977 Water Sharing Agreement on the Ganges, the situation improved slightly, but at the expiration of the second memorandum of the 
understanding (1985 MOU) in 1988 the dry season flow of the Gorai River started to drop sharply once again with decreases in the Ganges river discharge. Based on available data, Mirza (2004) further reported that in the third week of December 1992, the Gorai River dried up completely. Mirza and Sarker (2004) showed that the river systems of the southwestern region of Bangladesh had been affected by coastal saline water inflow in the month of November which reached a maximum in April and May. It may be true that natural causes also have significant influence on the inter-annual variations of salinity, but fluctuations of the Ganges water flow, as controlled by the Farakka Barrage, may be the most important factor (Mirza 1996; Mirza and Sarker 2004). Mirza and Sarker (2004) recorded the highest level of salinity in 1992 for February, March and April months when the flow in the Gorai River dropped down to zero. Reportedly, in April 1992 salinity rose to $29,500 \mathrm{~m}$-mhos/cm which was $1800 \%$ higher than preFarakka average (Mirza and Sarker 2004). As a whole, the salinity situation has been aggravated in the southwestern coastal region of Bangladesh during the post- Farakka period. By analysing salinity data of the southwestern coastal region for 20 years (1977-1997), the EGIS (2001b) study found that the 'slightly saline area' had increased $701 \mathrm{~km}^{2}$, the 'slightly to moderately saline' area had increased $501 \mathrm{~km}^{2}$, the 'moderately to highly saline' area had increased $2509 \mathrm{~km}^{2}$ and the 'highly saline' area had increased $1594 \mathrm{~km}^{2}$. The study concluded that absolute salinity in the southwestern region of Bangladesh has increased many times over the years. Since 1996, when the second Ganges Treaty was signed, the situation has improved slightly, but increase in salinity has been continuing due to rise of sea level and increased tidal surge (Agrawala et al. 2003; Mirza et al. 2008). The use of saline water for irrigation makes areas more saline through the accumulation of salts in the soil profiles. ${ }^{6}$ Consequently, salinity in soil has also increased in the southwestern coastal region of Bangladesh since construction of the Farakka Barrage (Khalid 2010; Mirza and Hossian 2004). Both penetration of seawater and capillary rise of saline water from the underground water table are believed to be responsible for increased salinity in soil in greater Khulna and Jessore districts of Bangladesh (Mirza and Hossian 2004). Bangladesh Water Development Board (BWDB) (1993) measured and compared soil salinity of Meherpur, Naraial and Satkhira districts (these southwestern districts of Bangladesh are dependent on the fresh water flow of the Padma for agriculture and other daily requirements) at

\footnotetext{
${ }^{6}$ Two salinity thresholds are considered in estimating the discharge requirements in the Gorai and Ganges rivers. FAO (1976) recommended a $750 \mathrm{~m}-\mathrm{mhos} / \mathrm{cm}$ salinity level for irrigation. However, MPO (1987) accepted a level of $2000 \mathrm{~m}-\mathrm{mhos} / \mathrm{cm}$ for the worst case scenario.
}

$15 \mathrm{~cm}$ depth (m-mhos/cm at $\left.25{ }^{\circ} \mathrm{C}\right)$ for the year 1978 and 1992 and noticed a considerable increase in salinity of soil during the dry months.

The Sundarbans (World's largest single tract of mangrove), stretching between Bangladesh and India, is complexly dissected and watered by older distributaries of the Ganges, interconnected through a great web of meandering tidal rivers and creeks. Adequate supply of freshwater is required to sustain ecosystem health of this unique saline water swamp forest. However, a number of studies have found an increase in salinity and sedimentation in rivers and creeks of the southwestern coastal region of Bangladesh, particularly the rivers that flow through the Sundarbans and supply freshwater to this important ecosystem during the post-Farakka period (Bharati and Jayakody 2011; Crow et al. 1995; EGIS 2001a; Mirza and Sarker 2004; Potkin 2004; Swain 1996). Some experts are suggesting augmentation of flow in the Ganges by constructing a barrage inside Bangladesh near Pangsa (where the Padma meets the Bhramaputra) to check salinity and stop further intrusion in the southwestern coastal region of Bangladesh (Bandyopadhyay 1992; Potkin 2004, Nishat and Faisal 2000). India, in response, has proposed an inter-basin transfer of water and completed a survey and investigation for interlinking of the Ganges River with the Sundarbans (The Daily Star 2012). Referring to the Indian water resource minister, the same source also published news of a survey on linking Jogighopa (at the Brahmaputra)-TeestaGanges (at Farakka) as an alternative to Manas-SankoshTeesta-Ganges link project. However, there is skepticism about the idea. Specifically, some argue that interlinking could further increase dry land salinity, since the majority of the rivers of the Ganges plain and northeast India originate from the Himalayan mountain ranges where concentration of total dissolved solid is low and most of the rivers flow through arid or semiarid regions of the Ganges plain (Misra et al. 2007).

Salinity intrusion is a threat to environmental security, particularly for the lower riparian regions of the Ganges (Rashid and Kabir 1998). Bangladesh has been troubled with increased salinity in the southwestern part of the country caused by decline in the inflow of the Ganges. Despite the claim that "withdrawal of 40,000 cusec at the Farakka would have practically no effect at all" (Parua 2010), scientific investigations have established that salinity in dry season has significantly increased in the greater Khulna areas of Bangladesh since 1976 (Karim et al. 1982; Mirza 2004).

\section{Declining groundwater level at the Ganges basin}

The southwestern region of Bangladesh is naturally poor in groundwater resources. The region is fully dependent on 
the Ganges river system for agriculture and other activities. Only four percent of the national usable groundwater resources of 45,738 million cubic meters $(\mathrm{mcm})$ are available as usable groundwater in the southwestern region of Bangladesh. Available useful groundwater is estimated at $1958 \mathrm{mcm}$ (MPO (Master Plan Organization) 1986). Moreover, relatively low rainfall and associated high evapo-transpiration creates high demand of water for irrigation in this region. Excessive withdrawal of groundwater for irrigation, limited recharge and decreased flow from the groundwater table to the river as a 'base flow' have resulted in lowering of the groundwater table in different parts of Khulna division (Mirza 2005). Decline of the groundwater table has become more evident in Khustia and Jessore districts of Bangladesh during the dry season; in many areas of these districts the water table has dropped below $7 \mathrm{~m}$ from the pre-diversion period (Mirza 2004). Excessive ground water withdrawal through hand and deep tube-wells is the primary cause of ground water table declination, yet reduction in surface and in sub-surface flow due to obstructions created by dams and barrages have also slowed down ground water recharge process, contributing further to a declining ground water table (Crow et al. 1995).

\section{Flood, sedimentation and riverbank erosion}

Bangladesh and India have built many dams and embankments in the GBM river systems to control floods and facilitate irrigation, but their contribution to flood control is small compared to expectations as observed by many studies (Aylward et al. 2005; Faisal 2002). The Ganges Treaty, albeit others, focuses only on sharing of water during dry period, skipping responsibility for monsoon heavy flow regulation. Therefore, in case of heavy rain in upstream, Bangladesh becomes victim of floods as a downstream country; but the issue was overlooked in the Farakka water sharing treaty. Erosion of riverbank may occur during flood or when a river changes course. Every year Bangladesh experiences erosion of riverbanks, especially in the Brahmaputra river system because of large seasonal variations in flows of the river and gradual loss of depth in channel due to increased sedimentation (Biswas 2008; Mirza et al. 2005). Aylward et al. (2005) showed that both flood occurrence and riverbank erosion have increased both in Bangladesh and India in the post-Farakka period due to drainage congestion and unregulated flow of monsoon water.

Being situated between the Himalayas, where most of the rivers originate, and the Bay of Bengal, where the rivers finally meet crossing the country, Bangladesh bears the brunt of flooding in the GBM region (Mirza et al. 2005). With $80 \%$ of Bangladesh's land area prone to flooding, the country is an extremely vulnerable to flood and other water related hazards. Even in a normal year, about $30 \%$ of the country is flooded (Biswas et al. 2004; Mirza et al. 2005). A variety of factors like flash floods from neighbouring hills, inflow of water from upstream catchments, spilling of overbank of rivers from in-country rainfall, and congestion of drainage are responsible for flooding in Bangladesh. The situation becomes disastrous when flood-peaks synchronise in all the three rivers (Biswas and Uitto 2001; Mirza et al. 2005). Sedimentation which is being carried by the GBM rivers from the mountains to the plains, contributes to aggravating the situation through raising beds of rivers by significantly reducing the water holding capacity of the rivers. Any diversion of water or structure for withdrawal, therefore, decreases the velocity of the current of water and increases rate of sedimentation and worsens the flood effect (Biswas 2008).

The sedimentation, on the other hand, is regarded as a blessing for the region. Sedimentation contributes to forming the vast Indo- Gangetic alluvial plains. The proposed interlinking of rivers may cause large reduction in deposition of sediment, which could affect natural land upgradation process of the flood plains for cultivation. Moreover, it could distort the formation of emerging islands along the southern coast of Bangladesh (Misra et al. 2007).

\section{Agriculture and irrigation}

The Ganges and its distributaries flow through the northwest and some parts of the southwest region of Bangladesh, which are naturally drought-prone areas. Local agriculture of those areas is used to coping with this situation using irrigation from surface water sources from the Ganges and its distributaries, ponds, and other water bodies (Bharati and Jayakody 2011; Mirza 2004). Mirza (2004) noticed a significant reduction of availability of surface water during dry season in the post-Farakka period in the lower Ganges basin. Hydrological drought combined with regular meteorological drought aggravates the overall situation in the lower Gages basin (Mirza 2004).

Over the years agriculture practices in the lower Ganges have gone through a transformation. Introduction of High Yielding Varieties (HYV), mostly in the Boro season, has significantly increased demand for irrigation from midseventies and onwards. Bharati and Jayakody (2011) found that ground water based irrigation by deep and shallow tube wells considerably increased in the post -Farakka period due to increased demand for water and decreased availability of surface water in the Ganges and its distributaries and tributaries. Due to withdrawal of water at the Farakka during the dry season, the water level in the lower Ganges has dropped abruptly and most of its 
distributaries become dry (Mirza and Hossian 2004). BWDB (1993) reported that due to less rainfall and shortages of water in the G-K canals, a considerable amount of crops were damaged.

The dry season surface water scenario in the lower Ganges has indicated a conflicting present and troublesome future. Transfer of the so-called 'surplus water' to 'water deficit areas' through river linking project would add another conflicting dimension. The concept of 'surplus water' is itself faulty, since a reduction of surplus/flood water will affect the supply of surface water in terms of quantity and quality. Reduction in surface water causes reduction in ground water (i.e., lowering of surface water increases the demand for ground water for irrigation in some areas) and other areas may experience problems related to water logging which also affect crop yields. In both cases, either cost of production will be high or productivity will be reduced which will have direct affect on farmers (Misra et al. 2007).

\section{Drainage congestion and adverse location}

India and Bangladesh have built embankments on a number of major trans-boundary rivers in order to control flood and facilitate irrigation. But the embankments have been creating drainage congestion on both sides, though the problem is more acute in upstream area. India has built embankments on the Kodalia and Isamati rivers that have affected the downstream reaches of these rivers inside Bangladesh, resulting in serious scarcity of water in the dry season. In many places, the borderline has crossed the common rivers separating the countries and in some instances the river itself has become the boundary line. Naturally, meandering rivers can shift their course quite frequently; such shifting may lead disputes to ownership over newly accreted lands. Problems regarding adverse location also exist in the Ganges and the Kusiyara (a branch of the Barak in India) rivers. The situation becomes complicated with human intervention in the form of embankments, causing erosion to the opposite banks. Bank erosion of the Muhuri River is interpreted as such a category of dispute (Nishat and Faisal 2000).

\section{Human migration}

Either voluntarily or involuntarily people migrate from one place to place due to environmental, political, religious or racial reasons. Bangladesh's recurrent environmental disasters and associated migration statistics, both internally and externally, seem to document that occurrences of involuntary or forced migration have increased significantly over the years. Swain (1996) argues that large numbers of migrations from Khulna and Rajshahi region (the Ganges basin) have resulted from the Farakka induced water scarcity. This author opines that the Ganges water issue between Bangladesh and India could be cited as an example of cooperation in some instances, but is mostly an excellent case study of an inter-state conflict where two state actors are striving to acquire one scarce water resource by rationally calculating their interest in a zero-sum situation. The resulting environmental destruction in a vast region of Bangladesh has forced river-dependent people to migrate. Ahmed (2009) also conducted a research in the Khulna-Satkhira and Rajshahi regions to explore causes of migration and found $67 \%$ people migrate due to environmental insecurity. The Farakka Barrage led hydrological drought in the winter season has been an important causative factor for migration in the region.

\section{Environmental security in context of trans- boundary water resources management}

Many factors influence the issue of environmental security in case of trans-boundary natural resources management. Some of the elements that need to be taken into consideration include: ecological dynamics, population change, degree of access to the environmental resources, and so on. Interaction among the determinants of environmental security sets the stage for addressing the environmental security challenges (Dalby et al. 2009). Generally, environmental insecurity has two dimensions in spatial and causal senses, i.e., national and transnational. The transnational environmental insecurities can be far-reaching, and global in terms of cause and effect, but also may be capable of disrupting national and regional environmental orders of closer neighbors (Farooque 2004).

Every river system is an indivisible physical unit, and as such its management should consider the maximum welfare of the whole community irrespective of political jurisdictions. In case of trans-boundary rivers, the physical unity of the water makes it a 'shared natural resource', which creates an opportunity of cooperation between states. The UN General Assembly adopted resolution 3129 (XXVIII) accepting the 'shared natural resources' concept and declares "the importance and urgency of safeguarding the conservation and exploitation of natural resources shared by two or more states, by means of an effective system of co-operation". Thus, it is the obligation of a state with shared natural resources to consider its neighbours who are likely to be affected, regarding environmental consequences that may rise due to any of their interventions or lack of the same.

Understanding environmental security with particular emphasis on protection of the environment itself is required 
to highlight common concerns that can help to counterbalance the preoccupation with competing state interests (Najam 2003). Based on the experience of the Rio Bravo (US/Mexico), Spring (2007) suggested a 'hydro-diplomatic' approach as a strategy for resolving trans-boundary water related conflicts. A number of strategies could be adopted under this approach: for instance, technologies to increase supplies, negotiations on the local, regional and international political level (top-down) as well as by social and economic organizations (bottom up), institution building for training, development of policy, norms and laws, public works and a culture of water as identity processes (Dalby et al. 2009).

\section{Conclusions}

Analysis of trans-boundary water regimes runs the risk of being off-marked if detailed complexity of cooperation is not explicitly considered. A narrow focus on the existence of data-sharing between some Indian and Bangladeshi institutions instead of very active political nuances of interstate relations related to the water sharing conflict on the GBM rivers may not be adequate. The foundational issues that underpin the water conflict (which cannot in any case rationally exclude upstream Nepal) may be overlooked if a broad viewpoint is not considered (Zeitoun and Mirumachi 2008). The value of cooperation over the selected issues should be understood within the political context of riparian interactions. Conceptualizing 'environmental security' is primarily concerned with potential conflict over scarce or degraded resources, but its scope should be broadened to consider environmental problems beyond national interests.

All available socio-environmental data show that in South Asia the cost of non-cooperation in water regime management is higher than that of co-operation (Adhikary et al. 2000). The best example of non-cooperation is Bangladesh and India, where both countries have been suffering from many environmental impacts arising from geopolitical constraints of trans-boundary water resources management. Experiences indicate that over a longer time frame, the countries have no other alternatives but to cooperate with each other in managing their trans-boundary rivers.

The non-cooperative country-specific management options have led to water disputes in this region, which are ranked amongst the most well-known trans-boundary water conflicts in the world (Salehin et al. 2011). Several attempts have been made to resolve these disputes, but mostly these were inadequate to capture potential regional cooperation in the GBM basins on a number of issues, including water, generation and distribution of hydropower, flood management, navigation system, and improvement of water quality and management of watershed.

An integrated development framework for transboundary water resources management may be invoked between Bangladesh and India. The GBM countries may learn from agreements such as the Indus Treaty, Mekong River Agreement, and Nile Basin Initiative. Indeed, environmental security in relation to trans-boundary resources can only be achieved through an ecosystem orientation of international norms and regimes. For a longer-term solution, only water regimes built upon ecological criteria can ensure the security of the environment itself (Faisal 2002; Lebel et al. 2010).

Acknowledgments This work was partially financially supported by IUCN Bangladesh office under their Ecosystems for Life project and partially by Unnayan Onneshan. The authors would like to thank two anonymous reviewers for their very constructive comments on earlier draft, which helped to improve the article. The authors are thankful to Ms. Kazi Sunzida Lisa, Senior Lecturer, SESM, IUB for her help in preparing the map.

\section{References}

Abbas BM (1982) The Ganges Water Dispute. UPL, Dhaka Adhikary KD, Ahmad QK, Malla SK, Pradhan BB, Rahman K, Rangachari P, Rasheed KBS, Verghese BG (2000) Cooperation on Eastern Himalayan rivers: opportunities and challenges. BUP, Dhaka

Agrawala S, Ota T, Ahmed AU, Smith J, Aals MV (2003) Development and climate change in Bangladesh: focus on coastal flooding in Bangladesh. OECD working paper

Ahmad QK, Biswas AK, Rangachari R, Sanju MM (2001) GangesBrahmaputra-Meghna Region: A framework for sustainable development. UPL, Dhaka

Ahmed I (2009) Environmental refugees and environmental distress migration as a security challenge for India and Bangladesh. In: Brauch HS, Oswald Spring U, Grin J, Mesjasz C, Kameri-Mbote $\mathrm{P}$, Bahera NC, Chourou, C, Krummenacher H (eds) Facing Global Environmental Change: environmental, human, energy, food, health and water security concepts. Springer Berlin Heidelberg, pp 295-308

Alagh YK, Pangare G, Gujja (2006) Interlinking of rivers in India: overview and ken-betwa link. Academic Foundation, New Delhi

Amarasinghe U, Shah T, Malik R (2008) Strategic analyses of the National River Linking Project (NRLP) of India (Series 1). In: India's water future: Scenarios and issues. New Delhi: International Water Management Institute

Aylward B, Bandyopadhyay J, Belausteguigotia J, Borkey P, Cassar A, Meadors L, Voutchkov N (2005) Freshwater ecosystem services. Ecosystems and human well-being: policy responses. Island Press, Washington 3:213-255

Bandyopadhyay J (1992) Himalaya: prospects of and constraints on sustainable development. In: Peter BS (ed) The State of the World's Mountains: A Global Report. Zed Books, London, pp 93-126

Bandyopadhyay J (2004) Adoption of a new holistic paradigm is a precondition for integrated water management in India. Department of Science and Technology, Government of India, India 
Bandyopadhyay J, Perveen S (2008) The interlinking of Indian rivers: questions on the scientific, economic and environmental dimension of the project. In: Mirza MMQ, Ahmed AU, Ahmad QK (eds) Interlinking Rivers in India: Issues and Concern. Taylor and Francis, Abingdon, pp 53-76

Bandyopadhyay J, Rodda JC, Kattelmann R, Kundzewicz ZW, Kraemer D (1997) Highland Waters-a resource of global significance. In: Messerli B, Ives JD (eds) Mountains of the World: A Global Priority. Parthenon, New York

BBS (Bangladesh Bureau of Statistics) (1997) The Statistical yearbook. Dhaka, Bangladesh

Beach HL, Hamner J, Hewitt J, Kaufman E, Kurki A, Oppeneimer JA, Wolf AT (2000) Transboundary freshwater dispute resolution: theory, practice and annotated reference. United Nations University Press, New York

Bharati L, Jayakody P (2011) Hydrological impacts of inflow and land-use changes in the Gorai River catchment, Bangladesh. Water Int 36(3):357-369

Bisht M (2012) Tipaimukh Dam: some myths, some facts. IDSA comment. http://www.eurasiareview.com/26042012-indias-tipai mukh-dam-some-myths-some-facts-analysis/. Accessed 26 July 2013

Biswas AK (2008) Management of Ganges-Brahmaputra-Meghna System: way forward. In: Varis O, Tortajada C, Biswas AK (eds) Management of transboundary rivers and lakes. Springer

Biswas AK, Uitto JI (2001) Sustainable Development of the Ganges Brahmaputra-Meghna Basins. United Nations University Press, Tokyo

Biswas AK, Unver O, Tortajada C (2004) Water as a focus for regional development. Oxford University Press, Delhi

Brundtland GH (1987) Our common future: world commission on environmental development. The Brundtland-Report, Oxford University Press, Oxford, UK

BWDB (Bangladesh Water Development Board) (1993) Report on the effect of upstream withdrawal of the Ganges River flow on Bangladesh 1992-1993. Directorate of Ganges Studies, BWDB, Dhaka

Chaturvedi MC (2011) India's Waters: advances in development and management. CRC Press

Crow B, Alan L, Wilson D (1995) Sharing the Ganges. UPL, Dhaka

Cruz RV, Harasawa H, Lal M, Wu S, Anokhin Y, Punsalmaa B, Honda Y, Jafari M, Li C, Huu Ninh N (2007) Asia: climate change 2007: impacts, adaptation and vulnerability. In: Parry ML et al (eds) Climate change 2007: impacts, adaptation and vulnerability. contribution of working group II to the fourth assessment report of the intergovernmental panel on climate change. Cambridge University Press, New York

Dabelko GD, Mark H, Lonergan S, Matthew R (2000) State-of-the-art review on environment, security and development co-operation. Prepared for the Working Party on Development, Cooperation and Environment, OECD Development Assistance Committee, Paris. http://www.iisd.org/pdf/2002/envsec_oecd_review.pdf

Dalby S, Brauch HS, Oswald Spring U (2009) Environmental security concepts revisited during the first three phases (1983-2006). In: Brauch HS, Oswald Spring U, Grin J, Mesjasz C, Kameri-Mbote P, Bahera NC, Chourou B, Krummenacher H (eds) Facing Global Environmental Change: environmental, human, energy, food, health and water security concepts. 4:295-308

EGIS (Environment and Geographic Information Systems) (2001a) Environmental and social impact assessment of gorai river restoration project, vol I: Main Report. EGIS, Dhaka

EGIS (2001b) Contract research project on application of agroecological zones database in drought management and water availability assessment. EGIS, Dhaka

Elliott L (2001) Regional environmental security: Pursuing a nontraditional approach. In: Andrew THT, Kenneth BJD (eds) Non- traditional security issues in Southeast Asia. Select Publishing, Singapore, pp 438-467

Faisal IM (2002) Managing common waters in the Ganges-Brahmaputra-Meghna. SAIS Review 22(2):309-327

Falkenmark M, Rockstom J (2000) Water in emergencies: War and water. International Committee of the Red Cross, Geneva

FAO (Food and Agricultural Organisation of the United Nations) (1976) Water quality for agriculture, FAO Irrigation and Drainage Paper 29. FAO, Rome

Farooque M (2004) Environmental order: the security of survival. UPL, Dhaka

FPCO (Flood Plan Coordination Organization) (1993) Morphological studies: Southwest area water resources management project. Sir William Halcrow and Partners Ltd

Haftendorn H (2000) Water and international conflict. Third World Q 21(1):51-68

Haque MI (2008) Water resources management in Bangladesh. Anushilan, Bangladesh

Hasan S, Mulamoottil G (1994) Natural resource management in Bangladesh. Ambio 23(2):141-145

Hoque E (2012) Impacts of Tipaimukh projects on rivers and economy of Bangladesh. Economic Observer. http://www. economic-observerbd.net. Accessed 12 July 2013

Immerzeel WW, Ludovicus PH, Marc FPB (2010) climate change will effect the Asian water towers. Sci 328:1382. doi:10.1126/ science. 1183188

INHPC (Indian National Hydroelectric Power Corporation Ltd) (2012) http://www.nhpcindia.com. Accessed 12 February 2012

IWM (Institute of Water Modelling) (2005) Hydrological impact study of Tipaimukh dam of India on Bangladesh. Unpublished research report, Dhaka

Karim Z, Saheed SM, Salauddin ABM, Alam MK, Huq A (1982) Coastal saline soils and their management in Bangladesh. Bangladesh Soils publication No. 8, BARC p 33

Khalid AR (2004) The interlinking of rivers project in India and International water law: an overview. Chinese J Int Law 3(2):553-570

Khalid I (2010) Bangladesh Water Concern. South Asian Stud 25(1):73-87

Khan AH (1993) Farakka Barrage: its impact on Bangladesh-An Overview. Dhaka

Khan TA (1996) Management and sharing of Ganges. Nat Resour J 455:36

Kliot N, Shmueli D, Shamir U (2001a) Institutions for management of transboundary water resources: their nature, characteristics and shortcomings. Water Policy, pp 229-255

Kliot N, Shmueli D, Shamir U (2001b) Development of institutional frameworks for the management of transboundary water resources. Int J Glob Environ issues 1(3):306-328

Lebel L, Xu J, Bastakoti RC, Lamba A (2010) Pursuits of adaptiveness in the shared rivers of Monsoon Asia. Int Environ Agreem 10:355-375

Mahmood SZ (2009) The Dam documents. The Daily Star. http:// www.thedailystar.net/magazine/2009/07/04/followup.htm. Accessed 24 July 2012

Mirza MMQ (1996) Diversion of the Ganges water at Farakka and its effects on salinity in Bangladesh. Environ Manag 22(5):711-722

Mirza MMQ (2004) Hydrological changes in Bangladesh. In: Mirza MMQ (ed) The Ganges water diversion: Environmental effects and implications. Kluwer Academic Publishers, The Netherlands, pp 13-37

Mirza MMQ (2005) Vulnerability to the Ganges water diversion: adaptation and coping mechanisms. Water Sci Technol 49:247-285

Mirza MMQ, Hossian MA (2004) Adverse effects on agriculture in the Ganges basins in Bangladesh. In: Mirza MMQ (ed) The 
Ganges water diversion: Environmental effects and implications. Kluwer Academic Publishers, The Netherlands, pp 177-196

Mirza MMQ, Sarker MH (2004) Effects of water salinity in Bangladesh. In: Mirza MMQ (ed) The Ganges water diversion: Environmental effects and implications. Kluwer Academic Publishers, The Netherlands, pp 81-102

Mirza MMQ, Warrick RA, Ericksen NJ, Kenny GJ (1998) Trends and persistence in precipitation in the Ganges, Brahmaputra and Meghna basins in South Asia. Hydrol Sci J 43(6):845-858

Mirza MMQ, Warrick RA, Ericksen NJ, Kenny GJ (2005) Are floods getting worse in the Ganges, Brahmaputra and Meghna Basinss. In: Mirza MMQ, Ahmad QK (eds) Climate change and water resources in South Asia. Balkema Publishers, London, UK, A.A, pp 55-69

Mirza MMQ, Ahmed AU, Ahmad QK (eds) (2008) Interlinking of rivers in India: Issues and concerns. CRC Press/Balkema, Leiden

Misra AK, Saxena A, Yaduvanshi M, Mishra A, Bhadauriya Y, Thakur A (2007) Proposed river-linking project of India: a boon or bane to nature. Environ Geol 51:1361-1376

MPO (Master Plan Organization) (1986) National water plan. Ministry of Water Resources Development, Dhaka, Bangladesh

MPO (1987) National water plan. Ministry of Water Resources Development, Dhaka, Bangladesh

Myers N (1993) Ultimate Security: The environmental basis of political stability. New York, pp 101-103

Najam A (2003) The human dimensions of environmental insecurity: some insights from South Asia. Environ Change Security Project Report 9:59-73

Nishat A, Faisal IM (2000) An Assessment of the institutional mechanisms for water negotiations in the Ganges-BrahmaputraMeghna System. Int Negot 5:289-310

Parua PK (2010) The Ganga: water use in the Indian subcontinent. Vol 64, Springer Science and Business Media

Potkin A (2004) Watering the Bangladeshi Sundarbans. In: Mirza MMQ (ed) The Ganges water diversion: environmental effects and implications. Kluwer Academic Publishers, The Netherlands, pp 163-176

Rashid H (1977) Geography of Bangladesh. The University Press Limited, Dhaka

Rashid H (2012a) India's proposed river linking mega project. The Daily Star. http://www.thedailystar.net/newDesign/news-details. php?nid=225217. Accessed 7 March 2012

Rashid H (2012b) Teesta water issue: a few hard facts. The Daily Star. http://www.thedailystar.net/newDesign/news-details. php?nid=217791. Accessed 11 January 2012
Rashid HE, Kabir B (1998) Water resources and population pressures in the Ganges River basins, case study: Bangladesh. http://www. aaas.org/international/ehn/waterpop/bang.htm. Accessed 7 March 2012

Rosenberg DM, Mccully P, Catherine M (2000) Global-Scale environmental effects of hydrological alterations. BioSci 50(9):746-751

Salehin M, Khan MSA, Prakash A, Goodrich CG (2011) Opportunities for trans-boundary water sharing in the Ganges, the Brahmaputra, and the Meghna basins. India infrastructure report, 29

Sharma B, Sharma D (2008) Impact of climate change on water resources and glacier melt and potential adaptations for Indian agriculture. International Water Management Institute, New Delhi

Spring ÚO (2007) Hydro-Diplomacy: Opportunities for Learning from an Interregional Process. Integrated water resources management and security in the middle east. Springer, Netherlands, pp 163-200

Swain A (1996) The environmental trap: the Ganges river diversion, Bangladeshi migration and conflicts in India. Department of Peace and Conflict Research, Upsala University, Sweden

Tanzeema S, Faisal IM (2001) Sharing the Ganges: a critical anlaysis of the water sharing treaties. Water Policy 3:13-28

The Daily Star (2012) http://www.thedailystar.net/newDesign/newsdetails.php?nid=227039. Accessed 20 March 2012

The Ganges Treaty (1996) Treaty between the Government of Bangladesh and the Republic of India on sharing the Ganges/ Ganga water at Farakka. Delhi 12(12):96

Uitto JI, Duda AF (2002) Management of transboundary water resources: lessons from international cooperation for conflict prevention. The Geogr J 168(4):365-378

Ullman R (1983) Redefining Security. Int Secur 8:129-133

Wirsing RG, Jasparro C, Stoll DC (2013) International conflict over water resources in Himalayan Asia. Macmillan, UK

Wolf AT, Kramer A, Carius A, Dabelko GD (2005) Managing water conflict and cooperation. State of the World 2005: Redefining Global Security. World Watch Institute pp 80-95

World Bank (2000) Bangladesh: Climate Change and Sustainable Development (Bangladesh Report No. 21104-BD). Rural Development Unit, South Asia Region, World Bank

Zeitoun M, Mirumachi N (2008) Transboundary water interaction : reconsidering conflict and cooperation. Int Environ Agreem 8:297-316 